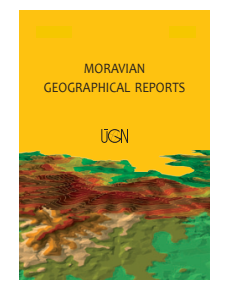

MORAVIAN GEOGRAPHICAL REPORTS

\title{
Coping with employment issues through commuting: Evidence from Central Russia
}

\author{
Maria GUNKO ${ }^{\text {* }}$, Tatyana NEFEDOVA ${ }^{\text {a }}$
}

\begin{abstract}
Commuting to work has become a widespread practice over the last several decades. Some relatively strong employment issues in rural Russian municipalities, as well as a significant wage gap between them and the major cities, fosters daily commuting as well as commuting with long periods of time spent at employment locations, known in Russia as otkhodnichestvo. Based on official statistical data and our own surveys conducted in Tula and Kostroma regions, we analysed the spatial differentiations between the share of commuters in the employed population of rural municipalities, as well as the variations in individual socio-economic characteristics between rural commuters and non-commuters, in general, and between the commuters themselves. Our analysis of the latter characteristics suggests that there is in fact more difference between the rural commuters and non-commuters in Russia than between daily commuters and those engaged in otkhodnichestvo, indicating similar motives and, perhaps, even personalities of commuters. Giving the identified differences, commuting on a larger scale does not seem to be a universal tool to cope with employment issues, as some population groups are more likely to engage in it than others.
\end{abstract}

Key words: Commuting, long-distance commuting, rural, post-socialist, Central Russia

Article history: Received 15 August 2016; Accepted 2 February 2017; Published 30 June 2017

\section{Introduction}

With improved transport systems, commuting to work is becoming a widespread practice in European societies (Bäckström, Sandow and Westerlund, 2016; Cassel, Macuchova, Rudholm and Rydell, 2013; Hofmeister and Schneider, 2010; Sandow, 2008, 2011). Commuting is caused by the variations in housing prices, wages and employment opportunities, and acts "as an equilibrating mechanism on the labour and housing markets" (Sandow, 2011, p. 2). Commuting provides access to employment opportunities on a wide geographical labour market without changes in residential arrangements (Lück and Ruppenthal, 2010; Plusnin, Zausaeva, Zhidkevich and Pozanenko, 2013; Sandow, 2011). Therefore, it is often viewed as an individual strategy alternative to migration (Hogarth, 1987; Mkrtchyan, 2010; Nefedova, 2015b; Sandow, 2011).

One specific characteristic of most European countries is their relatively dense urban networks with small distances between settlements, allowing daily short and long-distance commuting. In this context, commuting with a longer period of time spent at the employment site, e.g. weekly or monthly commuting, is a less frequent practice used to cope with employment issues (Sandow, 2011). In Russia, however, with its vast territory, sparse settlement network, poor transport connectivity and, most importantly, a small number of high-wage destinations (Zubarevich, 2013), commuting with longer periods spent at employment locations is quite common (Mkrtchyan, 2010; Nefedova, 2015a, 2015b; Plusnin, Pozanenko and Zhidkevich, 2015; Plusnin et al., 2013; Saxinger, 2015). Furthermore, the practice is explicitly and implicitly encouraged by employers, as such a workforce is often cheaper than the local one (Saxinger, 2015).

Some authors have argued that a significant number of people who are engaged in various forms of commuting in Russia come from peripheral rural areas (Nefedova, 2015a; Plusnin et al., 2013, 2015), as such places face the strongest employment issues (Nefedova, 2008, 2013b). In Central and Eastern European countries, in general, and in Russia in particular, the disadvantages of rural regions established under socialism - such as underdeveloped infrastructure, weak enterprises, and a deficiency of skilled labour forces (Leibert, 2013; Nefedova, 2013b) - have been reinforced under neo-liberal conditions. Currently, many such localities face a lack of job opportunities, which contributes to the selective out-migration of mainly economically active groups of the local population (Horváth, 2008; Kashnitsky and Mkrtchyan, 2014; Wastl-Walter and Váradi, Veider, 2003; Wiest, 2015) and encourages different types of commuting.

\footnotetext{
${ }^{a}$ Institute of Geography, Russian Academy of Sciences, Moscow, Russia (*corresponding author: M.Gunko, e-mail: msgunko@igras.ru)
} 
Despite the fact that commuting is widespread in contemporary Russia, the official statistical reports account for it in a poor manner. The existing statistical data do not permit one to confidently define the number of commuters in terms of the distance travelled to work, their commuting rhythms, and the period spent at employment locations not to mention the individual socioeconomic characteristics of commuters. Research of these noted issues is primary conducted with qualitative methods or is based on simple estimates (Mkrtchyan, 2010; Nefedova, 2015b; Plusnin et al., 2013). Against this background, this contribution seeks to shed more light on the commuting of Russian rural residents. The primary aim is to identify variations in the individual socio-economic characteristics distinguishing commuters and non-commuters in general, as well as between the commuters themselves, depending on the time they spend at their employment locations. Researching the commuting phenomenon in Russia as a part of the wider subject of population mobility, allows us to add to knowledge of the features of polarised spatial development in the postsocialist and especially post-Soviet context. In addition, it provides an interesting insight on labour mobility within a country with a very sparse settlement network, testing the assumptions of contemporary commuting theory.

The analyses used in the research are based on the statistical data from The Population Survey on Employment Issues (ONPPZ, 2013) and the Russian Population Census (VPN, 2010), and our own surveys which targeted adults living in rural peripheral municipal districts ${ }^{1}$ of the Kostroma and Tula regions, located in the so-called Nonchernozem ${ }^{2}$ part of Central Russia.

The structure of the paper is as follows: the first section deals with the conceptualisation of commuting. subsequently, rural development and commuting in Central Russia, in particular in the Tula and Kostroma regions, are described; the next section develops the data and methodological approaches, followed by the results of the study; in conclusion, our discussion attempts to overview the issues at hand.

\section{Conceptualising commuting}

Migration is explained to a great extent in terms of relative opportunity (Gilmartin, 2008), a balance between gaining access to better life opportunities elsewhere and a place-bound stability (Thulin and Vilhelmson, 2014), and is often triggered by adverse structural conditions (Chen and Rosenthal, 2008). There are many obstacles to changing place of residence, however, including structural barriers (e. g. disparity of housing prices) and subjective reasons, e.g. family and other social ties, place attachment (Barcus and Brunn, 2010; Hogarth, 1987; Massey et al., 1993). Nevertheless, to lead a more or less comfortable life, work is essential as a means to provide financial resources for most people. Therefore, some individuals overcome the impediments to taking employment outside their place of residence through commuting. Usually, a commuter is defined as an individual who crosses the administrative borders of a municipality when travelling to work (Cassel et al., 2013).
Depending on the distance and time of travel, commuting as a practice may be subdivided into short- and longdistance commuting. In the literature, long-distance commuting is often defined as a door-to-door journey to employment location which takes at least 40 minutes (Cassel et al., 2013; Sandow and Westin, 2010; Sandow, 2011). Given the distances and the underdeveloped transport infrastructures in Russia, ordinary daily journeys-towork within metropolitan regions, where daily commuting is most common, take around 1-2 hours (Makhrova, Nefedova, Treivish, 2013). Therefore, a high proportion of commuters in Russia are long-distance commuters if classified by European standards. Long-distance commuting is the outcome of a job search process where longer distance is traded for higher wages (Bäckström et al., 2016; Cassel et al., 2013; Sandow and Westin, 2010; Sandow, 2011; Saxinger, 2015; So, Orazem and Otto, 2001). The impact of the labour market on commuting relates to individual social characteristics, professional skills and education. Numerous authors argue that better-educated, primarily white-collar professionals are more mobile and prone to long-distance commuting (Cassel et al., 2013; Hogarth, 1987; Sandow, 2008). Their higher income levels reduce the relative travel costs (So et al., 2001). Furthermore, commuting, in general, and long-distance commuting, in particular, are gender imbalanced: on average, men commute to a larger extent than women in terms of the number and length of trips (Sandow and Westin, 2010; Sandow, 2011; Zhidkevich, 2013).

According to the duration of stay at the employment location, commuting may be performed daily or with a longer period of stay at that location, i.e. long-period commuting. Hogarth (1987) and Sandow (2011) argue that such commuting occurs when a person takes employment outside the comfortable temporal travel to work zone; therefore, it is logical to assume that the majority of longperiod commutes are carried out over a long or very long distance. Long-period commuting is often viewed as an extreme, problematic strategy (Bykov, 2011; Carrington, Hogg, McIntosh and Scott, 2012; Nefedova, 2015b). This type of commuting implies that a person lives in some type of lodging, for instance, during the week and returns home for the weekend (Hogarth, 1987). Other regular commuting rhythms are also possible, i.e. monthly or seasonally (Plusnin et al., 2013; Saxinger, 2015). Longperiod commuting may also be irregular, i.e. commuting with a sporadic rhythm. The phenomenon combining various types of long-period commuting (e.g. weekly, monthly), as well as the "fly-in, fly-out" mode of work (Perry and Rowe, 2015; Langdon, Biggs and Rowland, 2016; Saxinger et al., 2016) has become known in Russia as otkhodnichestvo (or vakhta). The term "otkhodnichestvo" originates from the old Russian word meaning "to depart", and was first used in the Russian Empire to define peasants who worked outside of their home regions during the cold seasons. This type of labour mobility has been widespread for several hundreds of years and disappeared only in the 1930s after collectivisation (Plusnin et al., 2015, 2013). Since the late 1980 s, however, overall population mobility has increased and otkhodnichestvo has again become a

\footnotetext{
1 The lowest unit of administrative-territorial division in Russia with an urban (county town) or a rural settlement as an administrative centre

${ }^{2}$ As established in Russian geography, the name for European regions of Russia with relatively low fertile soils and located mainly around and to the north of Moscow metropolitan region.
} 
significant practice, used to ensure the economic welfare of households and to provide workforce for the major cities and remote Northern-Eastern regions which specialise in natural resource extraction (Florinskaya, 2006; Plusnin et al., 2013; Saxinger, 2015; Shabanova, 1992).

\section{Rural development and commuting in Central Russia}

\subsection{Rural development as a prerequisite to commuting in Central Russia}

The differential development between dynamic, growing metropolitan areas and rural or old industrial regions experiencing processes of shrinkage and economic decline in many Central and Eastern European countries, including Russia, is often associated with the changed political system (Benedek and Moldavan, 2015; Fischer-Tahir and Naumann, 2013; Kühn, 2015; Lang, 2012). Territorial development is largely inertial, and the present inequalities which formed under socialism became the starting point for shaping inequalities under market conditions (Nefedova, 2008, 2013a; Smith, 1996). The planned economy had created and protected economic structures which are obsolete in the globalised neo-liberal economy. Market liberalisation and the emergence of competition for development resources only reinforced the differentiations in structural conditions and power relations.

The long-term concentration of population and economic activity in a handful of sparse foci in Russia has led to the formation of vast physically inaccessible, economically backward and depopulating areas of the periphery even in the 'heart' of Central Russia (Gritsay, Ioffe and Treivish, 1991; Ioffe, Nefedova and Zaslavsky, 2004, 2006). The socioeconomic development of such territories, which were poorly-equipped with infrastructure and which were uncomfortable for living already in the Soviet times, was based on the idea that human resources are inexhaustible (Nefedova, 2008, 2012). In the second half of the twentieth century this perception was fuelled by the 'euphoria' from oil revenues, which allowed the introduction and subsequent maintenance of expensive, unprofitable projects. Population development changed, low fertility rates and migration fostered rural depopulation. In the late Soviet period, crises could be traced to the labour-intensive economic activities located in rural districts (Ioffe, 1990). These unresolved development issues have had significant negative impacts in the post-socialist period. Many rural enterprises did not survive the harsh climate of global competition (Smith and Timar, 2010; Zubarevich, 2013). In the case of Central Russia, agriculture was for a long time the main sphere of employment in rural regions and districts. Unlike Central and Eastern European countries, new spheres of employment, such as services or tourism, hardly emerged in Russia's almost monofunctional rural areas (Nefedova, 2013). New enterprises in rural areas are still primarily specialised in agricultural activities, and are then located in southern regions which are favourable to agriculture or close to large centres to ensure demand for their produce. In the majority of Nonchernozem regions with less favourable natural conditions, agricultural enterprises balance on the brink of bankruptcy. Some of them try to preserve employment with the payment of minimum wages, which in fact resemble unemployment benefits
(Zubarevich, 2013). Therefore, some individuals in these areas end up in a situation of long-lasting unemployment and impoverishment (Nefedova, 2013a). As income sources have changed, households use different strategies to cope with the adverse structural conditions, often increasing the economic gap between them (Wegren, 2014).

Research on mobility in Russia indicates that, since the late 1990s, migration from structurally weak areas has been largely substituted by different types of commuting (Mkrtchyan, 2010). People are less prone to migrate due to the significance of local social ties in the everyday lives of a Russian household, which among other possibilities, promotes informal practices as a source of a household's income (Round and Williams, 2010), as well as the increasing disparity in housing prices between places of in- and outmigration (Nefedova, 2015b). The unemployment and wage differences between municipalities - which for blue collar workers may be around 3-4 times and for white collar workers up to 10 times, depending on home and employment locations (Nefedova and Treivish, 2014; Saxinger, 2015) promote the participation of rural residents in commuting to ensure their households' economic well-being.

\subsection{Commuting in the Kostroma and Tula regions}

Longstanding field research carried out in the rural peripheries of Nonchernozem regions has indicated that from one-fifth to one-half of officially registered rural dwellers are not engaged in any formal economic activity in their place of residence (Nefedova, 2013; Pokrovsky and Nefedova, 2014). While some constantly work or study in cities, others are regularly or occasionally engaged in various types of commuting. The data from The Population Survey on Employment Issues (ONPPZ, 2013) provide some insights on the number of commuters among the economically active population and the location of their employment. It presents data for three categories of workers: (1) working in the place of residence; (2) working outside the place of residence but within region of residence; and (3) working outside place and region of residence. Such a classification, unfortunately, does not permit us to confidently define daily commuters and otkhodniki ${ }^{3}$ among workers. According to the available data (ONPPZ, 2013), the overall number of various types of commuters in the Kostroma region is about 30 thousand people. For those working outside Kostroma region, the primary employment locations are Moscow, Moscow region, Yaroslavl, SaintPetersburg and Leningrad region (Tab. 1).

Using data from the latest Russian Population Census (VPN, 2010), which also does not differentiate daily commuters and otkhodniki, we have estimated the shares of intraregional commuters and commuters to other regions in the employed population of Kostroma region. These shares were further analysed according to the remoteness of commuters' place of residence (municipality) to the regional capital, i.e. Kostroma city (Fig. 1). Remoteness is measures as the order of municipality's neighbourhood to the regional capital, whereby zone 1 are municipalities directly bordering it. As it may be seen, the largest share of commuters working outside Kostroma region is characteristic not for peripheral districts with the strongest employment issues, but for the suburban ones. This finding corresponds to that of McQuaid, Greig, and Adams (2001): job seekers living in remote communities with low population density and higher

\footnotetext{
${ }^{3}$ People engaged in otkhodnichestvo
} 


\begin{tabular}{lcc}
\hline \multirow{2}{*}{ Commuting destination } & \multicolumn{2}{c}{ Share of commuters (\%) from } \\
\cline { 2 - 3 } & Kostroma region & Tula region \\
\hline Moscow city & 38.9 & 80.2 \\
Moscow region & 12.4 & 15.5 \\
Saint-Petersburg and Leningrad region & 8.8 & - \\
Yaroslavl & 19.4 & - \\
Other & 20.5 & 4.3 \\
\hline
\end{tabular}

Tab. 1: The destinations of commuters, including otkhodnichestvo, to other regions from Kostroma and Tula regions Note: *For Tula region the share of commuters to Saint-Petersburg and Yaroslavl is insignificant and is, therefore, presented in the category 'other'. Source of data: ONPPZ, 2013

unemployment levels are less willing to commute far to work. Slightly over $40 \%$ of Kostroma suburban residents commute, among them over 50\% commute outside Kostroma region. Beyond the suburbs of Kostroma city, the share of those working outside the region does not exceed 7\%. A significant proportion of the local rural population is comprised of intraregional commuters who work not only in Kostroma but also in smaller cities of the region, e.g. Manturovo, Sharya.

A different situation may be viewed in the Tula region, where the estimated number of commuters was about 80 thousand people (ONPPZ, 2013). The vast majority of them work in Moscow and Moscow region (Tab. 1). Research suggests that in the districts of Tula region, bordering the Moscow region, every third person works in Moscow or the Moscow region (Nefedova, Averkieva and Makhrova, 2016). While Tula city attracts commuters primarily from its own suburbs (Fig. 2).

Such variations of commuters' employment locations between Kostroma and Tula regions may be explained by the fact that Tula region borders the Moscow region, and some enterprises located in that region offer corporate transportation to commuters from nearby districts of Tula region (Gunko, 2015; Nefedova, Averkieva and Makhrova, 2016).

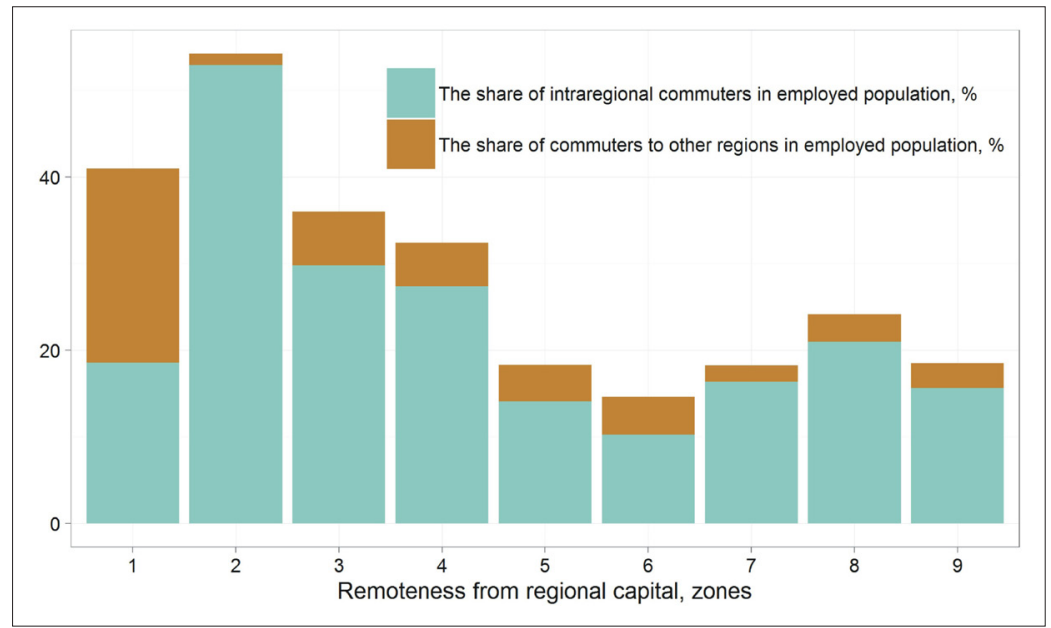

Fig. 1: The share of intra-regional commuters and commuters to other regions in the employed population of Kostroma region. Source: VPN, 2010; draft by T. Nefedova; design by M. Gunko

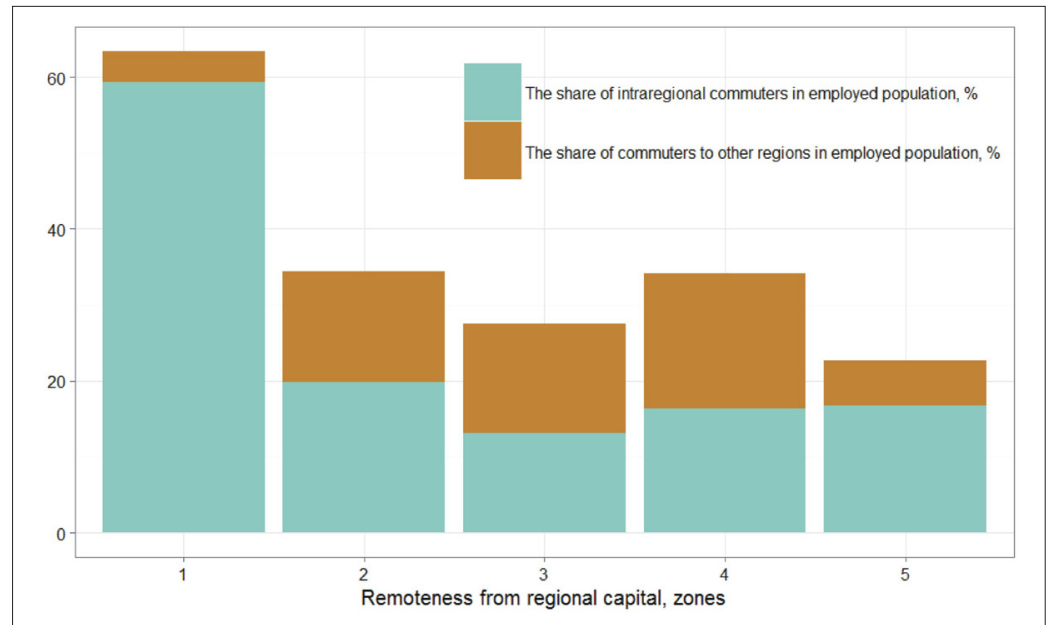

Fig. 2: The share of intra-regional commuters and commuters to other regions in the employed population of Tula region. Source: VPN, 2010; draft by T. Nefedova; design by M. Gunko 


\section{Research design}

\subsection{Case study: rural municipal districts}

The case study districts are located within the Nonchernozem area of Central Russia, which is infamous for the presence of persistent, long-lasting and reinforcing negative effects on the local labour markets after the transition from the planned to a market economy (Gunko, 2015; Nefedova, 2013a; Zubarevich, 2013). Four typical peripheral rural districts were selected: they are peripheral both in terms of spatial (i.e. remote from large cities) and aspatial features, e.g. they are depopulated areas which are heavily subsidised from regional and federal budgets (Copus, 2001; Kühn and Weck, 2012; Plöger and Weck, 2014). Makarievsky (7,616 rural resindents) and Shariyinsky districts (9,564 rural residents) are located in Kostroma region; Efremovsky (23,254 rural residents) and Suvorovsky districts (16,823 rural residents) in the Tula region. Giving the large area of the case study rural districts (Makarievsky - 1,066 sq.km, Efremovsky - 1,649 sq.km, Shariyinsky - 3,993 sq.km, Makarievsky - 4,850 sq. $\mathrm{km}$ ), as well as the low density of paved roads within them (BDPMO, 2015) ${ }^{4}$, a car trip from the most remote rural settlements to the districts' administrative centres often takes over an hour.
Three of the four districts have only one urban settlement (6,695 people in Makariev, 23,914 in Sharia, 36,161 in Efremov), which serves as their administrative centre. Suvorovsky district has two urban settlements (Suvorov - 17,615 people and Chekalin - 965 people). The population of most rural settlements (from $62 \%$ in Efremov district to $82 \%$ in Sharia district) does not exceed 50 people. Additionally, long-term rural depopulation (from $-15 \%$ in Efremovsky district to $-45 \%$ in Makarievsky district in the post-Soviet period) contributes to the relative increase of the smallest rural settlements' share in the total population.

Employment in the case study rural districts has traditionally been in agriculture, state-financed public services (e.g. education, healthcare) and public administration, accompanied by the emergent smallscale entrepreneurial activities, primarily trade, in the post-socialist period. Along with these activities in the districts of Kostroma region, which is the richest region of Central Russia in terms of timber resources, the harvesting and primary processing of wood is also widespread. The present unemployment rates in the case study rural districts resemble each other and do not exceed $3-5 \%$ (BDPMO, 2015). This indicator is measured by the Russian statistical agency, as the share of economically active individuals who have voluntarily registered in the

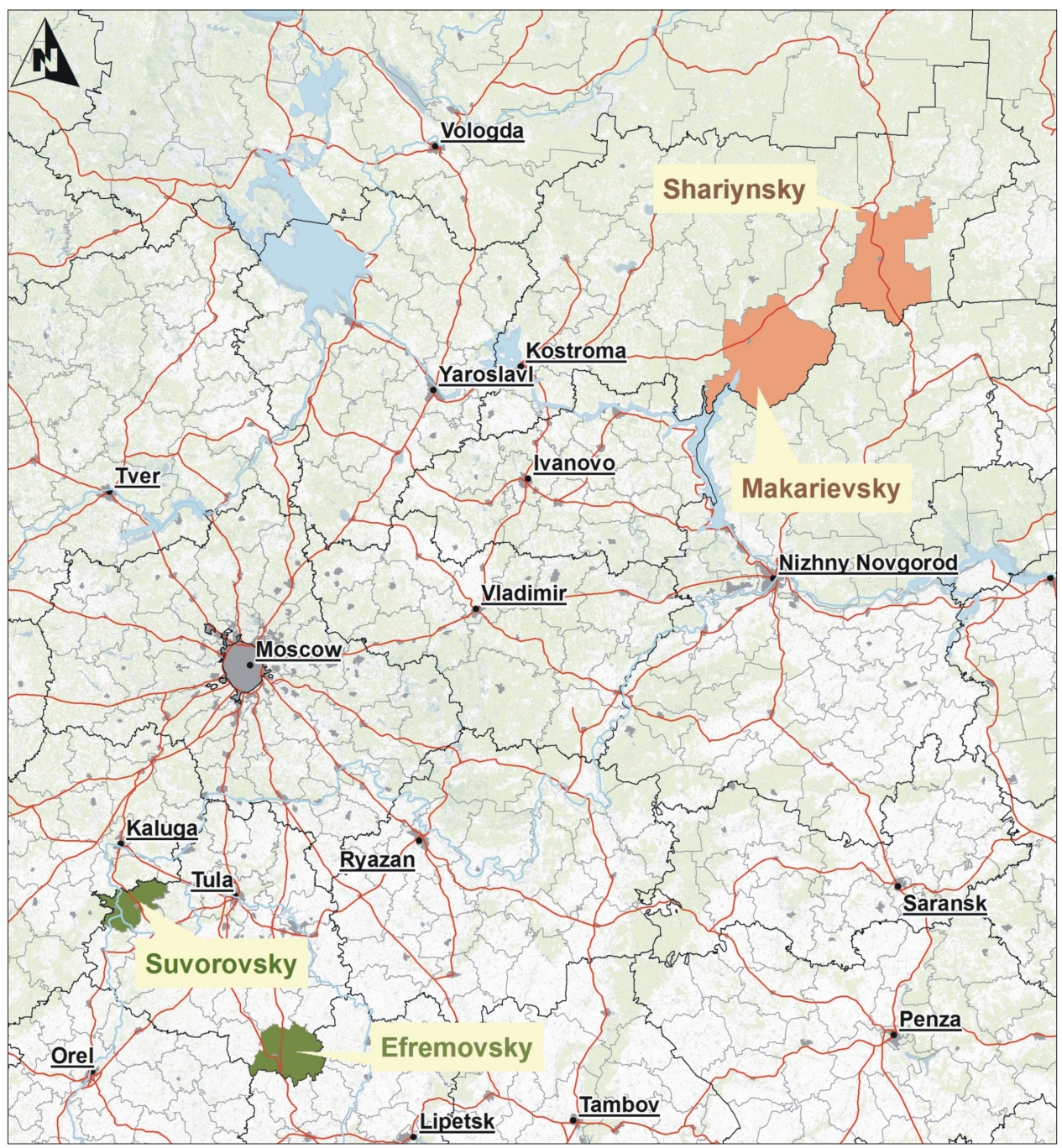

Fig. 3: Rural municipality case study areas. Source: draft by M. Gunko; design by A. Medevedev

\footnotetext{
${ }^{4}$ All figures in Section 4.1 are according to BDPMO (2015)
} 
territorial public unemployment services. Therefore, a number of researchers have argued, based on their own surveys, that the real level of unemployment in Nonchernozem rural districts sometimes exceeds 20\% (Aseeva, 2013; Bondarenko and Grudneva, 2010; Gulyaeva and Grigorieva, 2012; Gunko, 2015).

\subsection{Data}

Our study analyses the differences between the socioeconomic characteristics of daily commuters and otkhodniki, as well as between overall commuters and non-commuters from the rural districts. The target group for the study was defined as adults (between 18-65 years old), residing in Makarievsky, Shariyinsky, Suvorovsky, and Efremovsky rural municipal districts. Data were collected between May and August 2014 in the form of a questionnaire survey. The questionnaires were handed out to randomly selected people who fitted the age criteria and filled out on the spot.

The questionnaire was designed to collect quantitative information regarding type of employment (commuter or non-commuter, daily commuters or otkhodniki) and items relevant for the study socio-economic characteristics of the individual and household. These characteristics included age, gender, family status, type of employment of the spouse (commuter or non-commuter), presence of children in the household, number of children, and the type of transport used to get to work.

Overall, people were open to participation: the non-response rate was around 5\%. A total of 257 people were surveyed in the four municipalities. Among the surveyed, 121 were male and 136 female. The median age of the respondents was 44 years. The majority, 227 respondents, were married. 233 respondents had at least one child who was a minor. 92 respondents were commuters, 52 of them otkhodniki.

\subsection{Methodological approach}

In our analysis, we dealt primary with categorical variables. Therefore, multiple logistic regression models were estimated in order to statistically analyse and compare the socio-economic characteristics of commuters and noncommuters (Model 1), as well as daily commuters and otkhodniki in the chosen municipal districts (Model 2). In multiple logistic regression, the dependent variable is binary - coded as 0 and 1 . The categorical independent variables in our model were coded into binary dummy variables. The only numeric variable, age, for the ease of the analysis was also coded into a dummy variable, where 0 represented younger (18-40 years old) and 1 older (41-65 years old) working age groups.

Eight of nine independent variables included in the models are informed by the findings of previous commuting studies (e.g. Cassel et al., 2013; McQuaid et al., 2001; Sandow and Westin, 2010; Sandow, 2008). The inclusion of the ninth independent variable, engagement in supplementary economic activity, was dictated by the need to consider the specificity of socio-economic conditions of rural life in postSoviet Russia. As argued by A. Smith and Timar (2010), there is a broad set of widespread practices undertaken by households in the post-Soviet regions in response to economic marginalisation. The income from performing such activities is often kept 'off-record' not to pay taxes and may constitute up to one-third of the family budget (Gunko, 2015). Therefore, the engagement of the household members in supplementary economic activities in the place of residence may also act as factor affecting the choice to commute. All variables used in the analysis are summarised in Table 2.

\section{Results}

Prior to conducting the main analysis, we checked for the effect of location on commuters' numbers and features. The effect was found to be statistically insignificant, suggesting that there is little variation between the number and socioeconomic characteristics of commuters in the four districts under study. Then we estimated two logistic regression models: Model 1, 'commuters vs. non-commuters', Model 2, 'daily commuters vs. otkhodniki'. The output of Model 1 is presented in the Table 3, the reference group is commuters (non-commuters $=0$ ). The output for Model 2 is presented in Table 4, the reference group is otkhodniki (daily commuters $=0$ ).

In Model 1 (commuters vs. non-commuters), of the 9 independent variables, 5 have a significant effect on the dependent variable. In Model 2 (daily commuters

\begin{tabular}{|c|c|}
\hline Variable & Definition \\
\hline \multicolumn{2}{|l|}{ dependent variable: } \\
\hline type of employment & $\begin{array}{l}\text { equals to } 1 \text { if a person commutes, } 0 \text { otherwise (Model } 1 \text { ); equals to } 1 \text { if a person is an otkhodnik, } \\
0 \text { if a person is a daily commuter (Model } 2 \text { ) }\end{array}$ \\
\hline \multicolumn{2}{|l|}{ independent variables: } \\
\hline age & equals to 1 if the person is over 40,0 otherwise \\
\hline gender & equals to 1 if female, 0 otherwise \\
\hline family status & equals to 1 if married, 0 otherwise \\
\hline education & equals to 1 if respondent has university education, 0 otherwise \\
\hline type of spouse's employment & equals to 1 if the spouse is a commuter, 0 otherwise \\
\hline children & equals to 1 if a respondent has a minor child, 0 otherwise \\
\hline number of children & equals to 1 if a respondent has more than one minor child, 0 otherwise \\
\hline transportation to work & equals to 1 if respondent uses personal transport to get to work, 0 otherwise \\
\hline supplementary economic activity & $\begin{array}{l}\text { equals to } 1 \text { if a household is engaged in a supplementary informal economic activity } \\
\text { (except for self-sustaining farming), } 0 \text { otherwise }\end{array}$ \\
\hline
\end{tabular}

Tab. 2: Dependent and independent variables

Source: authors' definitions and computations 


\begin{tabular}{|c|c|c|c|c|c|}
\hline & Estimate & Std. Error & $z$ value & $\operatorname{Pr}(>|z|)$ & Sig. \\
\hline (intercept) & -1.556 & 1.533 & -1.015 & 0.310 & \\
\hline gender & -2.581 & 0.516 & -4.999 & 0.000 & Yes \\
\hline education & -0.806 & 0.453 & -1.779 & 0.075 & No \\
\hline family status & 2.523 & 1.106 & 2.280 & 0.022 & Yes \\
\hline type of spouse's employment & 0.084 & 0.533 & 0.158 & 0.874 & No \\
\hline children & 0.221 & 1.173 & 0.189 & 0.850 & No \\
\hline number of children & 2.314 & 0.499 & 4.632 & 0.000 & Yes \\
\hline supplementary economic activity & -1.298 & 0.433 & -2.992 & 0.002 & Yes \\
\hline age & -1.782 & 0.450 & -3.959 & 0.000 & Yes \\
\hline transportation to work & -0.282 & 0.430 & -0.656 & 0.512 & No \\
\hline
\end{tabular}

Tab. 3. Output for Model 1: 'commuters vs. non-commuters' (significance level $=0.05$ ) Source: authors' computations

\begin{tabular}{|c|c|c|c|c|c|}
\hline & Estimate & Std. Error & $z$ value & $\operatorname{Pr}(>|z|)$ & Sig. \\
\hline (intercept) & 15.412 & 1455.397 & 0.011 & 0.991 & \\
\hline gender & -2.376 & 0.718 & -3.306 & 0.000 & yes \\
\hline education & -0.153 & 0.629 & -0.244 & 0.807 & no \\
\hline family status & 13.128 & 1455.398 & 0.009 & 0.992 & no \\
\hline type of spouse's employment & 1.256 & 0.839 & 1.497 & 0.134 & no \\
\hline children & 0.211 & 1.183 & 0.177 & 0.880 & no \\
\hline number of children & 1.053 & 0.163 & 0.906 & 0.365 & no \\
\hline supplementary economic activity & -1.987 & 0.850 & -2.337 & 0.019 & yes \\
\hline age & 0.512 & 0.648 & 0.791 & 0.428 & no \\
\hline transportation to work & -0.612 & 0.581 & -1.052 & 0.292 & no \\
\hline
\end{tabular}

Tab. 4: Output for Model 2: 'daily commuters vs. otkhodniki' (significance levels $=0.05$ )

Source: authors' computations

vs. otkhodniki), only two independent variables have a significant effect on the dependent - gender and engagement in supplementary economic activity. This may indicate that there is less difference between the socio-economic characteristic of different types of commuters than between commuters and non-commuters in typical peripheral rural districts of Central Russia.

The first point to note is that gender has a statistically significant effect on the type of employment. On average, male respondents are more prone to commute, and especially to commute over longer distances and with a long period of stay in employment locations. This phenomenon was found in many previous studies (e.g. Sandow and Westin, 2010; Sandow, 2011). It may be explained both by the fact that women are more likely to find employment closer to home (Hanson and Pratt, 1995) and by the uneven share in domestic responsibilities, such as child-care and other household-related work (Hjorthol, 2000).

The second independent variable with a statistically significant effect in both models is the engagement in supplementary economic activity. The results suggest that having any type of supplementary economic activity which brings income, reduces the likelihood that the respondent is a commuter. Moreover, households of daily commuters are on average more likely to be engaged in such activities than households of otkhodniki. Such results may be interpreted in two ways, and we believe that to a certain degree both explain the obtained result. The first explanation is that otkhodniki themselves simply cannot engage in supplementary economic activities within the settlement of residence due to long periods being away from home, while their spouses are also short on time, being overloaded with household-related work which they have to perform alone. The second explanation may be that otkhodnichestvo is an extreme practice to overcome economic marginalisation, utilised only when all other options in the place of residence have been exhausted. The findings of previous qualitative studies on otkhodniki in Russia implicitly support this hypothesis. The majority of otkhodniki are either manual workers, e.g. construction workers, or people working in the service sector, e.g. security guards, retail store workers, taxi drivers or nannies (Plusnin et al., 2015, 2013; Savoskul, 2013); i.e. they are less legible and are willing to occupy those employment niches which do not require a special education and are generally not taken up by the local population. This is not a surprise, as the main destinations for otkhodniki are the metropolitan regions of Moscow and Saint-Petersburg, as well other large cities where the spheres of highly-qualified employment are more competitive than their low-skilled counterparts. Moreover, having a university degree is negatively associated with the chances that the respondent is a commuter, although it is not a significant factor affecting employment type in both models. This result is contrary to those obtained for Western European countries (Cassel et al., 2013; Hogarth, 1987; Sandow, 2008), where higher educated individuals are more prone to commute and to commute over longer distances.

Being married increases the chances that the respondent is a commuter, supporting the previous findings of Bäckström et al. (2016) and Sandow (2011) that the decision to commute 
is associated with family status and is carried out more often by households than by individuals. The presence of a minor child in a household also increases the likelihood that the respondent accepts the commuting strategy. As argued by Green (1997), households with children are less prone to migration and in adverse employment conditions substitute it by commuting. Although, in both of our models this factor is not statistically significant, having more than one child, which implies an increase in the minimum required living costs, is a statistically significant factor favouring commuting in Model 1.

Younger people are on average more likely to become commuters (Model 1). Besides the obvious explanation associated with the high labour expenditures of commuting, the obtained regularity could also be connected to the presence of minor children in the household since in Russia, especially in rural regions, the average age of parents having their first child is below 30 years. In Model 2 age has no significant effect on the variables.

\section{Discussion and conclusions}

The present inequalities as well as the current economic crisis in Russia caused by the decrease in oil prices, sanctions and counter-sanctions, can be projected to an increased spatial socio-economic polarisation. In such situations, rural regions are especially vulnerable, as the high unemployment rates there affect the intensification of migration and commuting. In the two regions analysed in this study, $15-60 \%$ of rural dwellers from the different municipalities commute to work. The variations in the share of commuters among the employed population is related to the municipality's location. Suburban residents were more prone to commute, and more likely to be otkhodniki, than residents of more remote peripheral municipalities who on average commute over shorter distance. The primary commuting destinations from Tula and Kostroma regions include the metropolitan regions and major cities of European Russia, mirroring general migration trends (Kashnitsky and Mkrtchyan, 2014; Zayonchkovskaya and Mkrtchyan, 2009).

Commuting and especially otkhodnichestvo is not just a specific form of labour mobility, but rather a peculiar lifestyle characterised by multi-localities (Plusnin et al., 2015; Saxinger, 2015) and implying a new social status and economic behaviours of those who perform it. Little is still known, however, about the individual socioeconomic characteristics defining commuters from the bulk of the population in Russia.

The aim of our study was precisely to analyse the differences between the socio-economic characteristics of rural commuters and non-commuters in contemporary Russia, as well as the difference between the two types of commuters - daily commuters and otkhodniki, drawing on the empirical evidence from rural municipalities in Central Russia. Some variables associated with commuting, including gender, age and the presence of minor children, as defined in previous studies (e.g. Cassel et al., 2013; Sandow, 2011), have been confirmed in this research. One significant difference is in terms of education. Having a university degree has an opposite effect on Russian commuters than on those analysed in previous studies with empirical evidence from European countries (e.g. Cassel et al., 2013; Hogarth, 1987; Sandow, 2008). Russian commuters seem to be less educated than non-commuters.
The observed variation, though statistically insignificant, could mean that people with a university degree either migrate or it is easier for them to find employment in the place of residence.

Our analysis suggests that there are in fact more differences between commuters and non-commuters in Russia than between daily commuters and otkhodniki. This may not only indicate that the motives of the latter are the same but also that there are similarities between them in terms of personality. Plusnin et al. (2015) argue that commuters, and especially otkhodniki, are proactive individuals, and this is also supported by Chepurenko (2010) who indicated that many potential entrepreneurs choose to be engaged in daily commuting or otkhodnichestvo, rather than start their own business due to the difficulties of starting and maintaining a business in Russia. Such issues, especially with respect to commuters' personalities, however, require further research.

Being utilised by specific social groups means commuting on a wide scale is not a universal remedy to cope with employment issues, and it seems to be more a temporal tactic than a sustainable strategy. Even for those currently engaged in commuting and otkhodnichestvo, it is hard to predict how long will they be willing to undertake such work, especially in a situation when economic crisis rapidly alters the conditions of labour markets in the main destinations of employment. Furthermore, places which attract commuters clearly receive a lot of benefits, such as low-cost labour, additional tax revenues and demand for goods and services, while the commuters' home regions suffer from workforce shortages in the sphere of low-wage employment as well as the reductions of tax and non-tax revenues in municipal budgets. Instead of mitigating adverse employment conditions, commuting contributes to the further deterioration of the situation on the rural labour markets reinforcing the overall spatial socio-economic polarisation of Russian regions. Though, it must be noted, that effects of commuting are far more complex than it may seem at a first glance. The potential positive effects, primarily in the social sphere resulting from high population mobility, are less visible and harder to research. However, they do require close attention in further studies.

\section{Acknowledgement}

A special gratitude is expressed to all survey participants. The authors would also like to thank Ilya Kashnitsky and Andrey Medvedev for the help with data visualisation. The research was supported by the Russian Scientific Foundation, grant No. 14-18-00083: "Geography of Recurrent Population Mobility within the Rural-Urban Continuum”.

\section{References}

ASEEVA, A. (2013): Rinok truda i zanyatost naseleniya v selskoy mestnosti Kurskoy oblasti Vestnik Kurskoy Gosudarstvennoy Selskokhozyastvennoy Akademii, 2: 21-24.

BÄCKSTRÖM, P., SANDOW, E., WESTERLUND, O. (2016): Commuting and timing of retirement. The Annals of Regional Science, 56: 125-152.

BARCUS, H., BRUNN, S. (2010): Place elasticity: exploring a new conceptualization of mobility and place attachment in rural America. Geografiska Annaler, Series B: Human Geography, 92(4): 281-295. 
BDPMO (2015): Database of municipal statistics [online]. Russian Federal Statistical Agency website [cit. 30.07.2016]. Available at: http://www.gks.ru/free_doc/ new_site/bd_munst/munst.htm

BENEDEK, J., MOLDAVAN, A. (2015): Economic convergence and polarization: towards a multidimensional approach. Hungarian Geographical Bulletin, 64(3): 187-203.

BONDARENKO, L., GRUDNEVA, A. (2010): Sostoyanie selskogo rinka truda. Uroven Zhizni Naseleniya Regionov, 3: 24-32.

BYKOV, V. [eds.] (2011): Formirovaniye konkurentnosposobnogo personala $\mathrm{v}$ usloviyakh vakhtovogo metoda raboty: na primere neftegazovoy otrasli. Yaroslavl, Avers Plyus.

CARRINGTON, K., HOGG, R., MCINTOSH, A., SCOTT, J. (2012): Crime talk, FIFO workers, and cultural conflict on the mining boom frontier. Australian Humanities Review, 53: 1-14.

CASSEL, S. H., MACUCHOVA, Z., RUDHOLM, N., RYDELL, A. (2013): Willingness to commute long distance among job seekers in Dalarna, Sweden. Journal of Transport Geography, 28: 49-55.

CHEN, Y., ROSENTHAL, S. S. (2008): Local amenities and life-cycle migration: Do people move for jobs or fun? Journal of Urban Economics, 64: 519-537.

CHEPURENKO, A. (2010): Small entrepreneurship and entrepreneurial activity of population in Russia in the context of economic transition. Historical Social Research, 35(2): 301-319.

COPUS, A. K. (2001): From core-periphery to polycentric development: concepts of spatial and aspatial peripherality. European Planning Studies, 9(4): 539-552.

FISCHER-TAHIR, A., NAUMANN, M. (2013): Introduction: Peripheralization as the social production of spatial dependencies and injustice. In: Fischer-Tahir, A., Naumann, M. [eds.]: Peripeharalization. The making of spatial dependences and social injustice (pp. 9-26). Wiesbaden, Springer.

FLORINSKAYA, U. (2006): Trudovaya migratsiya iz malikh gorodov kak sposob vizhivaniya. Sotsiologicheskie Issledovaniya, 6: 79-89.

GILMARTIN, M. (2008): Migration, identity and belonging. Geography Compass, 2(6): 1837-1852.

GREEN, A. (1997): A question of compromise? Case study evidence on the location and mobility of strategies of dual career households. Regional Studies, 31(7): 641-657.

GRITSAY, O., IOFFE, G., TREIVISH, A. [eds.] (1991): Tsentr i periferiya v regionalnom razvitii. Mosow, Nauka.

GULYAEVA, T., GRIGORIEVA, N. (2012): Rynok truda: problemi zanyatosti selskogo naseleniya v Orlovskoy oblasti. Vestnik Orlovskogo Gosudarstvennogo Agrarnogo Universiteta, 34(1): 158-162.

GUNKO, M. (2015): Vzaimosvyazi malikh gorodov i selskikh rainov v Tsentralnoy Rossii. Thesis [online]. Institute of geography RAS website [cit. 25.06.2016]. Available at: http://www.igras.ru/sites/default/files/announcements/ Gunko_diss.pdf
HANSON, S., PRATT, G. [eds.] (1995): Gender Work and Space. International Studies of Women and Place. London, Routledge.

HJORTHOL, R. J. (2000): Same city - different options: an analysis of the work trips of married couples in the metropolitan area of Oslo. Journal of Transport Geography, 8: 213-220.

HOFMEISTER, H., SCHNEIDER, N. (2010): Job mobilities in Europe: Core findings, policy implications future outlook. In: Schneider, N., Collet, B. [eds.]: Mobile Living Across Europe II. Causes and Consequences of Job-Related Spatial Mobility in Cross-National Perspective (pp. 337-356). Opladen, Barbara Budrich Publishers.

HOGARTH, T. (1987): Long distance weekly commuting. Policy Studies, 8(1): 27-43.

HORVATH, I. (2008): The culture of migration of rural Romanian youth. Journal of Ethnic and Migration Studies, 34(5): 771-786.

IOFFE, G. [eds.] (1990): Selskoe khozyaistvo Nechernozemya: territorialnie problemi. Moscow, Nauka.

IOFFE, G., NEFEDOVA, T., ZASLAVSKY, I. (2004): From spatial continuity to fragmentation: the case of Russian farming. Annals of Association of American Geographers, 94(4): 913-943.

KASHNITSKY, I. S., MKRTCHYAN, N. V. (2014): Russian periphery is dying in movement: a cohort assessment of Russian internal youth migration based on census data. NIDI Working Papers, 2014/14 [online]. Netherlands Interdisciplinary Demographic Institute website [cit. 9.08.2016]. Available at: www.nidi.nl/ shared/content/output/papers/nidi-wp-2014-14.pdf

KÜHN, M. (2015): Peripheralization: Theoretical Concepts Explaining Socio-Spatial Inequalities. European Planning Studies, 23(2): 367-378.

KÜHN, M., WECK, S. (2012): Peripherisierung - Prozesse, Probleme und Strategien in Mittelstädten. disP - The Planning Review, 48(2): 14-26.

LANG, T. (2012): Shrinkage, metropolization and peripheralization in East Germany. European Planning Studies, 20(10): 1747-1754.

LANGDON R., BIGGS H., ROWLAND B. (2016): Australian fly-in, fly-out operations: Impacts on communities, safety, workers and their families. Work, 55(2): 413-427.

LEIBERT, T. (2013): The peripheralization of rural areas in post-socialist Central Europe: A case of fragmenting development? Lessons from rural Hungary. In: FischerTahir, A., Naumann, M. [eds.]: Peripeharalization. The making of spatial dependences and social injustice (pp. 101-120). Wiesbaden, Springer.

LÜCK, D., RUPPENTHAL, S. (2010): Insights into mobile living: spread, appearances and characteristics. In: Schneider, N., Collet, B. [eds.]: Mobile Living Across Europe II. Causes and Consequences of Job-Related Spatial Mobility in Cross-National Perspective (pp. 37-68). Opladen, Barbara Budrich Publishers.

MAKHROVA, A. G., NEFEDOVA, T. G., TREIVISH, A. I. (2013): Moscow agglomeration and "New Moscow": The capital city-region case of Russia's urbanization. Regional Research of Russia, 3(2): 131-141. 
MASSEY, D., ARANGO, J., HUGO, G., KOUAOUCI, A., PELLEGRINO, A., TAYLOR, J.E. (1993). Theories of international migration: a review and appraisal. Population and Development Review, 19(3): 431-466.

MCQUAID, R., GREIG, M., ADAMS, J. (2001): Unemployed job seekers attitudes towards potential travel-to-work times. Growth and Change, 32(1): 66-73.

MKRTCHYAN, N. V. (2010): Migratsionnaya i mobilnost v Rossii: otsenki i problemi analiza. Demoscop Weekly, 445-446 [online]. Demoscop weekly website [cit. 20.07.2016]. Available at: http://www.demoscope.ru/ weekly/2010/0445/analit01.php

NEFEDOVA, T. (2008): Rossiiskay periferiya kak socialnoeconomichesky fenomen [Russian periphery as a socioeconomic phenomenon]. Regionalnie Issledovaniya, 20: $14-30$.

NEFEDOVA, T. (2012): Major trends for changes in the socioeconomic space of rural Russia. Regional Research of Russia, 2(1): 41-54.

NEFEDOVA, T. (2013a): Desyat aktualnikh voprosov o selskoy Rossii. Otveti geografa. Mosow, URSS.

NEFEDOVA, T. (2013b): Polyarizatsiya gorodov i selskoy mestnosti i rasshirenie rossiiskoy periferii. In: Artobolevsky, S., Glezer, O. [eds.]: Regionalnoe razvitie i regionalnaya politika Rossii v perekhodniy period (pp. 280-298). Moscow, MGTU im. Baumana.

NEFEDOVA, T. (2015a): Migration mobility of population and otkhodnichestvo in modern Russia. Regional Research of Russia, 5(3): 243-256.

NEFEDOVA, T. (2015b): Otkhodnichestvo $\mathrm{v}$ sisteme migratsii v post-sovetskoy Rossii. Geographiya Demoscop Weekly, 643-644 [online]. Demoscop weekly website [cit. 20.07.2016]. Available at: http://demoscope. ru/weekly/2015/0643/tema01.php

NEFEDOVA, T., AVERKIEVA, K., MAKHROVA, A. [eds.] (2016): Mezhdu domom i ... domom. Vozvratnaya prostranstvennaya mobilnost naseleniya Rossii. Moscow, Noviy Khronograf.

NEFEDOVA, T., TREIVISH, A. (2014): Russia between the two capitals: Specifics of territorial changes. Regional Research of Russia, 4(4): 207-219.

ONPPZ (2013): The Population Survey on Employment Issues [online]. Russian Federal Statistical Agency website [cit. 8.08.2016]. Available at: http://www.gks.ru/ bgd/regl/b13_30/Main.htm

PERRY, M., ROWE, J. (2015): Fly-in, fly-out, drivein, drive-out: The Australian mining boom and its impacts on the local economy. Local Economy, 30(1): 139-148.

PLÖGER, J., WECK, S. (2014): Confronting out-migration and the skills gap in declining German cities. European Planning Studies, 22(2): 437-455.

PLUSNIN, J., POZANENKO, A., ZHIDKEVICH, N. (2015): Otkhodnichestvo kak novy faktor obschestvennoy zhizni. Mir Rossii, 24(1): 35-71.

PLUSNIN, J., ZAUSAEVA, Y., ZHIDKEVICH, N., POZANENKO, A. [eds.] (2013): Otkhodniki. Moscow, Noviy Khronograf.
POKROVSKY, N., NEFEDOVA, T. [eds.] (2014): Potentsial blizhnego severa. Ekonomika, ekologiya, selskie poseleniya. Moscow, Logos.

ROUND, J., WILLIAMS, C. (2010): Coping with the social costs of "transition": Everyday life in post-Soviet Russia and Ukraine. European Urban and Regional Studies, 17(2): 183-196.

SANDOW, E. (2008): Commuting behaviour in sparsely populated areas: evidence from northern Sweden. Journal of Transport Geography, 16: 14-27.

SANDOW, E. (2011): On the road: Social aspects of commuting long distances to work. PhD thesis [online]. Digitala Vetenskapliga Arkivet website [cit. 8.08.2016]. Available at: http://www.diva-portal.org/smash/get/ diva2:415050/FULLTEXT01.pdfGERUM

SANDOW, E., WESTIN, K. (2010): The persevering commuter - Duration of long-distance commuting. Transportation Research Part A: Policy and Practice, 44: 433-445.

SAVOSKUL, M. (2013): Sidelki iz provintsii v bolshom gorode. Sotsialnaya Diagnostika, 113(1): 127-135.

SAXINGER, G. (2015): Lured by oil and gas: Labour mobility, multi-locality and negotiating normality and extreme in the Russian Far North. The Extractive Industries and Society, 3: 50-59.

SAXINGER, G., ÖFNER, E., SHAKIROVA, E., IVANOVA, M., YAKOVLEV, M., GAREYEV, E. (2016): Ready to go! The next generation of mobile highly skilled workforce in the Russian petroleum industry. The Extractive Industries and Society, 3: 627-639.

SHABANOVA, M. (1992): Otkhodnichestvo i rynok rabochey sily. Region: Ekonomika i Sotsiologiya, 2: 29-39.

SMITH, A., TIMAR, J. (2010): Uneven transformations: Space, economy and society 20 years after the collapse of state socialism. European Urban and Regional Studies, 17(2): 115-125.

SMITH, D. M. (1996): The socialist city. In: Andrusz, G., Harloe, M., Szelenyi, I. [eds.]: Cities after socialism. Urban and regional change and conflict in post-socialist societies (pp. 70-99). Oxford, Blackwell.

SO, K. S., ORAZEM, P. F., OTTO, D. M. (2001): The effects of housing prices, wages, and commuting time on joint residential and job location choices. American Journal of Agricultural Economics, 83(4): 1036-1048.

THULIN, E., VILHELMSON, B. (2014): Virtual practices and migration plans: A qualitative study of urban young adults. Population, Space and Place, 20: 389-401.

VPN (2010): Russian Population Census [online]. Russian Federal Statistical Agency website [cit. 8.08.2016]. Available at: http://www.gks.ru/free_doc/new_site/ perepis2010/croc/perepis_itogi1612.htm

WASTL-WALTER, D., VARADI, M. M., VEIDER, F. (2003): Coping with marginality: to stay or to go. Journal of Ethnic and Migration Studies, 29(5): 797-817.

WEGREN, S. K. (2014): Rural inequality in post-Soviet Russia. Problems of Post-Communism, 61(1): 52-64.

WIEST, K. (2015): Migration and everyday discourses: Peripheralisation in rural Saxony-Anhalt from a gender perspective. Journal of Rural Studies, 43: 280-290. 
ZAYONCHKOVSKAYA, Z. A., MKRTCHYAN, N. V. (2009): Rol' migratsii v dinamike chislennisti i sostava naselenija Moskvi. In: Zayonchkovskaya Z. [eds.]: Immigranti v Moskve (pp. 18-44). Moscow, Tri kvadrata.

ZHIDKEVICH, N. (2013): Sotsialny portret sovremennogo otkhodnika nizhegorodskogo Zavolzhiya. In: Shipilev, A. [eds.]: Region v period modernizatsii: sotsialnie instituti (pp. 118-121). Nizhny Novgorod, NISOC.
ZUBAREVICH, N. [eds.] (2013): Sotsialnoe razvitie regionov Rossii. Problemi i tendentsii perekhodnogo perioda. Moscow, URSS.

\section{Please cite this article as:}

GUNKO, M., NEFEDOVA, T. (2017): Coping with employment issues through commuting: Evidence from Central Russia. Moravian Geographical Reports, 25(2): 118-128. Doi: 10.1515/mgr-2017-0011. 